Article

\title{
Corporate Social Responsibility and Corruption: Implications for the Sustainable Energy Sector
}

\author{
Jintao Lu ${ }^{1,2, *(\mathbb{D})}$, Licheng Ren ${ }^{1,2}$, Jiayuan Qiao ${ }^{1}$, Siqin Yao ${ }^{1}$, Wadim Strielkowski ${ }^{3}$ and \\ Justas Streimikis 4 \\ 1 Department of Business Administration, School of Economics and Management, Taiyuan University of \\ Science and Technology, Taiyuan 030024, China \\ 2 Research Center for Corporate Social Responsibility, Taiyuan University of Science and Technology, \\ Taiyuan 030024, China \\ 3 Department of Trade and Finance, Faculty of Economics and Management, Czech University of Life Sciences \\ Prague, 16500 Praha-Suchdol, Czech Republic \\ 4 Lithuanian Institute of Agrarian Economics, 03105 Vilnius, Lithuania \\ * Correspondence: lut2002@163.com; Tel.: +86-35-1277-6604
}

Received: 8 July 2019; Accepted: 29 July 2019; Published: 31 July 2019

check for updates

\begin{abstract}
This paper focuses on the concept of Corporate Social Responsibility (CSR) and its relationship with sustainability. The authors investigate the linkages between CSR and sustainability at both enterprise and country levels. The main focus of this study is the energy sector due to its importance in terms of economic, environmental, and social impacts. There are some doubts as to whether a socially responsible business meets public welfare expectations and fosters the country's social and economic development, as well as the successful achievement of sustainable development objectives. However, it becomes apparent that the development of corporate social responsibility in the energy sector faces a plethora of challenges. Corruption is one of the most important challenges of sustainable energy development. The study analyzes the main areas of CSR policies where energy companies are expected to make a positive contribution to sustainable energy development: mitigation of environmental impact, economic and social development, and good governance. The authors argue that the corruption risks represent a very important issue that is hampering sustainable energy development, and CSR can be applied to mitigate these risks in the energy sector. In addition, government policies might be necessary to create a favorable environment for corruption risk mitigation. The study analyzes the main tools of corporate social responsibility in the energy sector and addresses the impact of CSR on the sustainability of energy sector and corruption risk mitigation. The study analyzes a corruption risk mitigation model in the energy sector and provides recommendations for strengthening corporate social responsibility and mitigating corruption risk. Our results show that CSR can play a vital role in dealing with corruption in the energy sector at the enterprise level. It becomes apparent that anti-corruption standards represent the main supporting means for achieving other CSR goals and principles. Therefore, mitigation of corruption risks should become a priority for socially responsible companies that are operating in the energy sector.
\end{abstract}

Keywords: corporate social responsibility; sustainability; energy; corruption

\section{Introduction}

Energy which represents the main driver of economic growth and has significant impact on the environment is crucial for achieving sustainable development [1]. Sustainable energy development is the main aim of energy policy in all countries around the world that are committed to sustainable 
development and climate change mitigation. There are three main dimensions of sustainable energy: (i) energy security; (ii) energy environmental sustainability; and (iii) energy equity [2]. For example, The World Energy Council's Energy Trilemma Index was created to rank countries based on the three main sustainability dimensions: (i) Energy Security; (ii) Energy Equity; and (iii) Environmental Sustainability [3]. In fact, the energy sector is presently facing a plethora of challenges that are concerned with sustainable development. In practice, despite the legal regulations, there are other important issues that strongly depend on the related stakeholders, the level of the transparency, market liberalization, as well as restructuring and competition in the energy sector. Even though climate change remains the most important and widely discussed environmental problem of sustainable energy development, there are other essential issues that have negative impacts on the achievement of all dimensions of sustainable energy development with corruption being one of them. Many researchers agree that it is one of the most serious problems linked to the energy sector, which has a negative impact on all other issues of the energy sector and most importantly its sustainability (see, e.g., Rimsaite (2019) [4]). This is linked to the political contestation and high influence of the energy companies on the economy. The promotion of renewable energy sources (RES) imposes new challenges for the sustainable energy development and corruption, as this is related to the market and institutional failures, liabilities of origin, and their transferability across market participants and across borders. In addition, technologically advanced countries like China are heavily investing in wind and solar energy much more than the European Union (EU), the United States (US), and Japan, and energy sectors in these countries are not liberalized and partially owned by the state [5]. The sector of renewable energy is especially vulnerable to corruption, as far as public subsidies are very attractive for criminals who are seeking for the formation of criminal associations between businessmen and politicians having the power to influence the licensing process and policy regimes for the promotion of renewables, especially in the countries with weak social capital and institutions [6].

The risk of corruption in the energy sector is linked to the supply chain of specific energy sources and their significance in a given country. The socio-political and institutional environment, in which extraction, transformation, and the use of energy carriers occur, plays an important role in defining corruption risks. The cultural environment in the country, the strengths of institutions, the enforcement of regulation, and the number of persons participating in the decision-making are of the key importance in the occurrence of the corruption risks [4]. A lack of transparency and accountability as poor legal and institutional systems creates conditions for the abuse of power and impunity of decision makers. In order to mitigate corruption risks, it is necessary to consider each of these issues simultaneously. It can help to mitigate corruption risks at the enterprise level that corporate control, prevention programs, and Corporate Social Responsibility (CSR) standards, including codes of ethics that are accordingly applied at the organizational level [7]. Corporate Social Responsibility initiatives guide and allow energy companies to implement principles of sustainability at the enterprise level and have a direct impact on the sustainable energy development on local and country level. However, government policies are more important in mitigating corruption risks in the energy sector [8]. Though the development and enforcement of anti-corruption laws have been emphasized during the past decades, which included huge fines for companies and imprisonment of guilty corporate executives, the problem of corruption is still relevant in the energy sector. The importance of proper legal regulation is linked to the fact that energy resources are located in the developing countries where governments have principal control over the decisions in the energy sector, especially in granting licenses and public procurement procedures [9].

The impact of CSR on corruption risk mitigation in the energy sector was investigated by several scholars who discovered that CSR has a positive impact on restraining managerial self-serving behavior in developed energy markets and countries that have strong institutions, high level of social capital, and active social integrity [9-11]. However, the CSR initiatives appeared to be less effective in mitigating corruption risks in emerging markets with weak regulation, ineffective institutions, and lower legal protection of private property and investments [12]. The developed energy markets play a significant mediating role. Therefore, the quality of institutions, social capital, and the level of 
market development maturity are the main drivers mediating positive impact of CSR on the restraining self-serving managerial behavior [9]. In addition, oil extraction and mining companies that represent controversial industries sometimes implement CSR in order to obtain legitimacy [13-17].

In 2000, when Global Compact was launched, its initial nine principles did not address the issue of corruption [18]. Nevertheless, it soon became apparent that unless corruption was tackled, the Global Compact would not be effective; and as a result, the tenth 'Anti-corruption Principle' was added in 2004. Other CSR instruments, such as the Organization for the Economic Co-operation and Development's (OECD) Guidelines for Multinational Enterprises and business self-regulation initiatives, such as codes of conduct of several multinational corporations, as well refer to the anti-corruption struggle as a shared responsibility of business sector [19-21].

Our paper analyzes the main tools of corporate social responsibility in energy sector and addresses the impact of CSR on the sustainability of energy sector and corruption risk mitigation. The paper offers both theoretical and policy implications inputs. It addresses the key areas of corruption risk and its impacts. Moreover, it develops corruption mitigation model for energy sector. This is a review paper based on the analysis of scientific literature and synthesis of the main findings. The main limitations of the applied approach are the lack of an empirical study.

The remainder of this paper is organized as follows. Section 2 provides a literature review on the CSR and sustainable energy development and corruption risks in the energy sector; Section 3 deals with the main drivers and impacts of CSR in the energy sector; Section 4 analyzes the ability of CSR to deal with corruption risks in the energy sector; Section 5 provides corruption risk mitigation model for the energy sector; Section 6 concludes and provides recommendations for strengthening corporate social responsibility and mitigating corruption risk in the energy sector.

\section{Literature Review}

\subsection{Corporate Social Responsibility in the Context of Sustainable Energy Development}

Since the concept of sustainable development represents a crucial concept for the development of modern energy sector, its practical implementation faces a large number of obstacles, mainly related to the inability of markets to solve monopoly power, environmental, public goods, information limitations, social inequality, and other problems inherited by the energy sector [22]. Though the liberalization of the energy sector has been achieved in many developed countries with a positive impact on the transparency and efficiency of energy industries, nevertheless, the free market cannot ensure the achievement of social and environmental objectives of sustainable energy development [23]. Therefore, the government interventions in the energy markets are necessary to tackle these problems, though the government regulation is unable to solve these problems on a global scale as well.

The EU introduced its Shared Responsibility policy that sets out new market approaches in order to reduce the negative impact on the environment and spread information widely [24]. On October 22, 2014, European Parliament (EP) and European Commission (EC) adopted a directive on disclosed non-financial information of corporates (PE-CONS 47/1/14), which provides that companies should disclose more extensive information on the sustainability of their activities in their annual accounts: the key social and environmental factors affecting their activities, their fair and comprehensive policies, and an overview of results and risks, as these should boost investor and consumer confidence, etc. The requirements of the Directive cover the key areas of social responsibility and refer to the core principle standards or reporting guidelines of social responsibility.

Alongside the regulatory requirements of mandatory environmental and labor relations which are defined by legal acts, new means are created in order to encourage enterprises to pursue better environmental and social standards [25]. Voluntary environmental and social activities are becoming an important factor in improving the image and reputation of a company [26-29]. In addition, this activity is economically viable and guarantees positive impact on the competitiveness and value of enterprises [30-33]. Governments, international organizations, and the general public became 
interested in the voluntary environmental activities of companies only recently (in the late 1980s) [34-36]. These corporate initiatives complement mandatory environmental and social requirements that are regulated by the governmental institutions.

The voluntary business initiatives, such as CSR, with their origins embedded in the concept of a social contract, play an increasingly important role in the global sustainable energy development policy. There are many voluntary initiatives aimed at promoting and improving CSR reporting at both global and micro levels, such as the United Nations Global Compact (GC), OECD Guidelines for Multinational Enterprises Carbon Disclosure Project (CDP), GRI G3 Guidelines, etc.: they are the key tools for enabling sustainable energy development and implementing these principles at all levels [37-40].

Therefore, the vision of sustainable development for the energy industries poses new challenges which are projected into the concept of CSR. Socially responsible energy companies need to analyze and properly evaluate social consequences of their activities and their environmental impact. The World Business Council for Sustainable Development (WBCSD) proposed the following definition of CSR: "an ethical behaviour of the enterprise towards the community which consists not only of shareholders but of a much wider circle of stakeholders with legitimate, business-related interests" [41,42]. Thus, it is clear that CSR is, perhaps, one of the three most important elements of sustainable energy development, though all these dimensions are closely linked. As a result, CSR in the energy sector is based on economic, environmental, and social dimensions and fully consistent with the concept of sustainable business due to the fact that each socially responsible company at the micro level can be regarded as sustainable and directly contributing to the goals of sustainable development [43-46].

The United Nations initiated the Global Compact in 1999 introducing the key tool for developing corporate social responsibility with an aim to encourage companies to carry out their business responsibly and without inducing any harm to the environment, community, companies operating on the market. Another goal was to join efforts with the UN, encourage governments and non-governmental sector to address specific social and environmental problems in society in order to contribute to the socially inclusive economic growth [47-50]. The 10 Principles of UN Global Compact allow addressing corruption issues [51], which are especially relevant for international energy companies that operate globally $[52,53]$.

In order to provide new opportunities and reduce operating costs for energy companies, the application of responsible business practices might help any company to create a competitive advantage for itself [54-56]. The responsible entrepreneurial practices can boost the company's profitability and improve its image. The publicly available information about corporate social responsibility helps to build trust and create an attractive and trustworthy employer's image. A socially responsible company can expect to have the best employees, attract as well as retain staff. This reveals clear links between sustainable or socially responsible companies, high organizational culture, and sustainable leadership [57-60].

The concept of CSR allows justifying the importance of sustainable business development in achieving sustainable energy development of the country [61-63]. As the major challenges of enterprises that are operating in the energy sector are linked to serving society and corruption threats, the corruption risks in the energy sector are addressed in the next section of this paper.

\subsection{The Risk of Corruption in the Energy Sector}

The risk of corruption in the energy sector is an important issue that needs to be addressed by governments, enterprises, NGOs, as well as the general public. Corruption risk that is defined by Transparency International is a potential probability that corruption may occur and the possible costs it might cause. The increase in the corruption risk provides a higher probability of corruption or higher cost linked to the probable corruption, or both. The decrease in the corruption risk provides the lower probability corruption occurrence or lower cost associated with corruption, or both. There are many important studies that are dealing with the cross-cultural drivers or determinants of corruption [64-67]. Based on the results of these studies, it becomes clear that the main drivers of corruption at a country's level are the level and pace of economic development, strengths of political institutions, activeness 
of civil society, and some cultural dimensions. In addition, formal and informal institutions have a direct impact on the outcomes of corruption in any given country. This happens due to the fact that ethical or unethical behavior of individuals and companies are shaped by societal norms and based on formal and informal institutions. The legal system has the main impact on the level of corruption that is available in a specific country. One can see that in countries with effective legal systems and good law enforcement, the corrupt officials are usually tracked down and punished [65].

Other studies investigated the effect of political institutions on controlling corruption. They demonstrate that the important drivers of corruption risk mitigation appear to be democracy, freedom, and the activeness of civil society $[6,67,68]$. The political competition and accountability that is linked to the good governance have a very positive impact on corruption mitigation [9]. For ensuring free political competition, fair elections are necessary. Such type of elections forces politicians to face their electorate and report on the implementation of their promises. The prevention of abuses of authority should be stipulated by organizing different branches of government in a way to restrain each other. The monitoring of executives is necessary by legislation and the enforcement of institutions, including the oversight of parliamentary committees. The transparency is the main feature of political competition and accountability. The main constituents of transparency are the freedom of press and expression, which have been shown by the press and government to mitigate corruption in the country [9]. In most of the studies dealing with corruption mitigation report that such indicators of institutional quality, enforcement of legislation on investor protection, and political freedom all have the decisive impact on the corrupt behavior. In addition, it was found in many studies that developed and emerging markets have significant differences in their institutional qualities $[67,68]$. There are only a few studies dealing with the measures envisaged to mitigate corruption risk on the enterprise level. Krishnamurti et al. [9] analyzed corruption risk in the defense industry and proved that institutional and governance quality and legislation enforcement are the best means to control corruption. It was found [9] that the power distance and uncertainty avoidance as well have significant influence on corruption risk at the enterprise level. Another study [9] proved that the visibility and shareholders involvement play a crucial role in mitigating corruption risk at the enterprise level. Therefore, all studies unanimously agreed that institutional indicators are the main drivers of corruption at the enterprise level. Several new studies found that stakeholders are more likely to trust high-CSR firms and their engagement by implementing CSR which could reduce the risks linked to the opportunistic behavior of the company's executives $[25,26]$. Usually, the managers of socially responsible companies are less keen to engage in selfish behavior than the executives representing firms with low CSR. Therefore, an enterprise with high scores of CSR are expected to be more ethical as they are likely to have a low risk of corruption $[25,26]$. Based on the conducted analysis of literature, it can be concluded that enterprise engagement in CSR activities mitigates its corruption risk.

In addition, several studies found that for energy companies which usually have a high corruption risk the impact of CSR depends on motives for the implementation of CSR and the economic development level of the country. The energy resources are mostly located in the countries that have underdeveloped infrastructure, institutions, and control systems which are unable to deal with the corruption risks. Africa, Latin America, Asia, and the Middle East are the main exporters of oil and gas resources and, in the same time, underdeveloped energy markets. Countries located in these regions usually have lower rankings in Transparency International Corruption Perceptions Index, i.e., they yield higher level of corruption risks [68].

There are many mergers and acquisitions that are happening in the energy sector, including state owned companies that are dominating the energy sector. In these undertakings, governmental officials are appointed to the supervisory board in order to ensure the interests of the state. Such stakeholders' appointments could create a situation that is favorable for the conflict of interests. The operating environment of the enterprise, location, and the nature of its activities all have an impact on the corruption risk in the energy sector. Taking into account monopolistic character of energy utilities, the public procurement has the major role in the corruption risk. Moreover, corruption risks may occur 
during the purchasing of products or services from utilities, especially if contracts and licenses are involved. The bribes may often be offered to managers that are performing the procurement function by enterprise in exchange for winning the tender. During bidding situations, several enterprises might agree in advance about the lowest price and compromise the bidding. In a situation when there are few suppliers, the risk of corruption increases. All these result in a violation of a fair competition and breaking the competition law. However, this situation is quite frequent in the energy sector [4]. Moreover, the breach of the public procurement can happen. There is a high corruption risk in state-controlled energy utilities during the appointment of board members in the supervisory board. Consequently, without duly implementing procedures for the appointment of supervisory board members, there is also a high risk of corruption in the energy utilities. The corruption risks can be mitigated if unanimous procedures of public procurement or the selection of board members would be applicable to all companies. Currently, each energy company being a part of the group has the right to make these decisions independently. The restructuring and unbundling of energy companies and the liberalization of energy markets can provide benefits for corruption mitigation in the energy sector [4]. The competitive markets exacerbate the negative effects of regulatory uncertainty of energy companies and the potential corruptive actions [69]. The literature review on the impact of energy market liberalization and the lessons that were learned from the other countries showed a positive impact on the corruption mitigation in the energy sector $[69,70]$. The energy utilities are usually considered as the party that is giving bribes, and governmental executives are regarded as the party that is demanding these bribes. The corruption risks in the energy sector are mostly linked to the important role of government in the energy sector due to the organization of tenders and granting licenses. In addition, the energy sector is heavily regulated and the main activities in this sector are licensed or require specific permits to be granted by the regulatory bodies and governmental officials. As the energy resources are usually found in poor and underdeveloped market economies that have weak political and social institutions, this makes corruption risks even higher. Therefore, the upstream oil and gas companies are especially exposed to the corruption risks [71]. In addition, most of the foreign governments are highly intricated in businesses that are operating in oil and gas sectors due to the abundance of state-owned enterprises, including joint ventures with a state [4].

Corruption risk is linked to the likelihood of corruption occurrence and anticipated negative impact of this phenomenon. High corruption risk ranking of a country signifies that the likelihood of a demanded bribe is greater than that in the other states. There is a sectoral corruption risk as well, which indicates that due to high regulation, enterprises that are operating in specific sectors are exposed to a higher corruption risk level. In the energy sector, transaction risks are linked to public procurement procedures, the licensing procedures, and the large number of suppliers and third-party intermediates, such as agents that are usually yielding high corruption risks. Therefore, the energy sector is highly regulated, and governmental agencies issue a lot of approvals that are represented by the licenses, approvals, permits, and exemptions that are necessary for the energy undertakings to operate. These permits and exemptions are linked to the environmental assessments, the exploitation of energy resources, imports, and exports of energy carriers, employment of local nationals, safety and environmental standards, and various taxes.

In addition, there are many corruption risks that exist in the renewable energy sector due to the fact that publicly supported renewable energy sources are able to attract criminal attention and favor the formation of illegal associations between business people and policy makers; in order to affect the tendering and licensing process [6]. The climate change policies, implemented in the energy sector, are as well linked to high corruption risks, as governments pledge to use billions for climate finance, but governance structures, managing the response to climate, are in the most climate and corruption vulnerable countries [68].

The corruption in the energy sector is a function of the size of the rewards under a public officials' control, the discretion that these officials have in allocating those rewards, and the accountability that the officials face for their decisions. As discretion increases and accountability decreases, the 
potential for corruption grows. Corruption can occur in all project cycles. In legal systems with higher regulatory interference in business, the incidence of corrupt practices is significantly higher. Various empirical studies proved the relationship between the extent of bribery and the amount of time that an enterprise's manger spends with public officials. The governmental regulations allow public officials to use them for corrupt practices. The main drivers of corruption are as follows: (i) the size of rewards and penalties under a bureaucrat's control, (ii) the amount of discretion they have for allocation of rewards and penalties, and (iii) the lack of accountability for their decisions and actions.

In order to combat corruption risk at the enterprise level, the compliance with the law should be ensured and the compliance programmes should be developed. Enterprises should develop the compliance programs in order to detect and prevent corruption by applying risk-based approach. The compliance programmes include risk assessment procedures and compliance actions related to the identified risk levels. These procedures require an understanding of both the probability that the bribe might be paid and the magnitudes that might occur if a bribe is paid. Therefore, it is necessary to evaluate these corruption risks and allocate enterprise compliance resources in a sensible way. The CSR practices include compliance programmes and corruption mitigation actions. One of the most important issues is personnel training and information provision.

In Table 1, the main corruption risks in the energy sector are identified by grouping them according to the project implementation cycle.

Table 1. The main corruption risks in the energy sector.

\begin{tabular}{|c|c|c|c|c|c|c|}
\hline $\begin{array}{l}\text { Influence of the } \\
\text { Energy Sector }\end{array}$ & $\begin{array}{l}\text { Selection of } \\
\text { Options }\end{array}$ & Project Planning & Contracting & Construction & $\begin{array}{l}\text { Operation and } \\
\text { Maintenance }\end{array}$ & Decommissioning \\
\hline $\begin{array}{l}\text { All sectors: } \\
\text { nuclear, oil, gas, } \\
\text { renewables, } \\
\text { electricity, heat, } \\
\text { energy storage, } \\
\text { etc. }\end{array}$ & $\begin{array}{l}\text { Undue political } \\
\text { influence in } \\
\text { setting the site } \\
\text { and type of } \\
\text { installation }\end{array}$ & $\begin{array}{l}\text { Undue political } \\
\text { influence on } \\
\text { technical } \\
\text { specifications and } \\
\text { cost assessment } \\
\text { biased to a } \\
\text { particular } \\
\text { technology }\end{array}$ & $\begin{array}{l}\text { Undue political } \\
\text { influence on the } \\
\text { selection of } \\
\text { contractor }\end{array}$ & $\begin{array}{l}\text { Undue political } \\
\text { influence on } \\
\text { construction cycle }\end{array}$ & $\begin{array}{l}\text { Undue political } \\
\text { influence on } \\
\text { operation and } \\
\text { maintenance }\end{array}$ & $\begin{array}{l}\text { Undue political } \\
\text { influence on } \\
\text { selection of } \\
\text { options, } \\
\text { contracting, etc. }\end{array}$ \\
\hline Preconditions & $\begin{array}{c}\text { Non } \\
\text {-transparent } \\
\text { process; } \\
\text { considered } \\
\text { limited options; } \\
\text { limited public } \\
\text { involvement }\end{array}$ & $\begin{array}{c}\text { Poor } \\
\text { Environmental } \\
\text { Impact } \\
\text { Assessment (EIA) } \\
\text { following } \\
\text { non-transparent } \\
\text { EIA clearance }\end{array}$ & $\begin{array}{l}\text { Non-transparent } \\
\text { prequalification; } \\
\text { confusing tender } \\
\text { documents; } \\
\text { non-transparent } \\
\text { selection } \\
\text { procedures; } \\
\text { tender } \\
\text { clarifications not } \\
\text { shared with } \\
\text { other bidders }\end{array}$ & $\begin{array}{c}\text { Concealing } \\
\text { sub-standard } \\
\text { work; agreeing to } \\
\text { unwarranted } \\
\text { contract } \\
\text { variations, delays, } \\
\text { creating artificial } \\
\text { claims; bribery to } \\
\text { avoid delay } \\
\text { payments; bribes } \\
\text { for resettlement } \\
\text { and compensation }\end{array}$ & $\begin{array}{l}\text { Commitments } \\
\text { not kept; } \\
\text { underfunding of } \\
\text { environmental } \\
\text { mitigations }\end{array}$ & $\begin{array}{l}\text { Non -transparent } \\
\text { process; } \\
\text { considered limited } \\
\text { options; limited } \\
\text { public } \\
\text { involvement and } \\
\text { non-transparent } \\
\text { selection } \\
\text { procedures }\end{array}$ \\
\hline Result & $\begin{array}{c}\text { Selection of } \\
\text { unnecessary } \\
\text { projects in } \\
\text { wrong locations }\end{array}$ & $\begin{array}{l}\text { Over-or under } \\
\text { design }\end{array}$ & $\begin{array}{l}\text { Deception and } \\
\text { collusion, } \\
\text { agent's fee }\end{array}$ & $\begin{array}{l}\text { Delays; increased } \\
\text { costs; construction } \\
\text { environment } \\
\text { violations }\end{array}$ & $\begin{array}{l}\text { Corruption in } \\
\text { operation and } \\
\text { maintenance } \\
\text { procurement, } \\
\text { insurance fraud } \\
\text { on equipment } \\
\text { and } \\
\text { performance } \\
\text { guarantees }\end{array}$ & $\begin{array}{c}\text { Delays; increase in } \\
\text { costs; } \\
\text { environmental } \\
\text { violations }\end{array}$ \\
\hline Impact & $\begin{array}{l}\text { Negative } \\
\text { environmental } \\
\text { impact }\end{array}$ & Waste of resources & $\begin{array}{l}\text { Waste of } \\
\text { resources and } \\
\text { selection of } \\
\text { worse possible } \\
\text { contractor }\end{array}$ & $\begin{array}{l}\text { Driving up costs, } \\
\text { delaying of the } \\
\text { project, lowering } \\
\text { service quality } \\
\text { and reliability }\end{array}$ & $\begin{array}{l}\text { Waste of } \\
\text { resources, costs } \\
\text { overruns, proper } \\
\text { functioning at } \\
\text { risk, increase in } \\
\text { accident } \\
\text { probability }\end{array}$ & $\begin{array}{c}\text { Driving up costs, } \\
\text { delaying of } \\
\text { implementation, } \\
\text { lowering quality } \\
\text { and reliability, } \\
\text { negative } \\
\text { environmental } \\
\text { impact }\end{array}$ \\
\hline
\end{tabular}

Source: Own results based on references $[4,6,9,15,18,72,73]$.

For assessing the corruption risk at a specific phase of a project cycle, it is necessary to define whether there is an incentive of a person to pay a bribe and what is the probability to make improper 
payment as well obstacles for executives to make questionable payments. In order to develop an effective legislation, there should be strict laws in place, prohibiting corrupt behavior in the country [4-7].

As can be noticed from Table 1, the corruption in the energy sector has a long-term negative impact on the country and all the stakeholders that are involved. The impact of corruption on the main stakeholders in the energy sector is presented in Table 2.

Table 2. The impact of corruption on stakeholders in the energy sector.

\begin{tabular}{|c|c|}
\hline Stakeholders & Impact \\
\hline Energy consumers & $\begin{array}{l}\text { Higher energy prices; less affordable and reliable energy supply; negative } \\
\text { environmental, health, and safety impacts. }\end{array}$ \\
\hline $\begin{array}{l}\text { Local inhabitants and } \\
\text { communities }\end{array}$ & $\begin{array}{l}\text { More negative environmental and social impact projects; fewer social or } \\
\text { external benefits; higher impoverishment risks; fewer funds for local } \\
\text { communities for compensation of damage, mitigation of negative impacts } \\
\text { and benefit-sharing; fewer climate change mitigation commitments and a } \\
\text { higher vulnerability to climate change. }\end{array}$ \\
\hline Energy companies & $\begin{array}{l}\text { Lower efficiency in operation; higher negative environmental impacts and } \\
\text { environmental taxes; higher costs of energy supply; higher interests and } \\
\text { borrowing costs, including higher equity costs; fewer financial resources for } \\
\text { service expansion and quality improvement; delayed and overpriced } \\
\text { infrastructure projects; higher debts, losses, and risk of bankruptcy. }\end{array}$ \\
\hline $\begin{array}{l}\text { Governmental institutions and } \\
\text { bodies }\end{array}$ & $\begin{array}{l}\text { Higher energy sector costs; higher budget spending for repayments of loans } \\
\text { or loans guarantees and support for vulnerable population; negative impact } \\
\text { on social and environmental policies implementation; negative } \\
\text { environmental impacts and related health impacts requiring more } \\
\text { mitigation actions; slower economic growth and job creation; increase in } \\
\text { energy and other poverty and vulnerability of population; increase in social } \\
\text { tensions, political instability risks, etc. }\end{array}$ \\
\hline $\begin{array}{l}\text { Independent Power Producers, } \\
\text { private business developers in } \\
\text { the energy sector }\end{array}$ & $\begin{array}{l}\text { Distortion of competition; unfair competition and efficiency losses; wasted } \\
\text { tender payments and other additional expenses and losses; rescinded } \\
\text { approvals, terminating the projects. }\end{array}$ \\
\hline Financing institutions & $\begin{array}{l}\text { Higher risks and dangers of reputation; higher demand for borrowing; } \\
\text { additional costs and fraudulent claims; adverse selection and moral hazard } \\
\text { problems; risk of bankruptcy and financial crisis. }\end{array}$ \\
\hline
\end{tabular}

As can be noticed from Table 2, the corruption has a very negative impact and high costs for all the stakeholders in the energy sector. Therefore, corruption mitigation practices should be implemented by all stakeholders at macro and micro levels. As CSR indicates priorities of ethical behavior by companies, these practices can help significantly in dealing with corruption in the energy sector.

\section{Implementing Corporate Social Responsibility in the Energy Sector: Drivers and Impacts}

The liberalization of the energy sector and development of IT technologies both provide more transparency and more advantages for the energy consumers. Nowadays, customers can get a clear overview on which company offers the best price for the same or similar products and services. It has now become a norm that a website can offer customers free of charge service of comparing prices between different energy providers as well as assistance in case they wish to switch from one energy provider to another. Therefore, any energy consumer can easily find out which energy provider offers the lowest price and make the switch. In addition, energy is a homogeneous product, and from a customer's perspective, it has identical features, benefits, and quality. This situation makes energy suppliers to compete by using prices and availability. Therefore, energy suppliers need to offer something more to make their customers loyal. Thus, they have to be proactive and study the upcoming trends in order to find out if these are applied to their customers before their competitors will. 
Currently, the main trend is corporate social responsibility (CSR) or sustainability. CSR is becoming an essential element of company strategies, given the recognized need to ensure the long-term success in the future [5]. Utilities are pursuing social priorities that extend far beyond prior concerns for reputation. CSR provides an opportunity and a source to create competitive advantages [2]. Moreover, consumers are becoming more informed and engaged in what products and services to buy.

Due to these trends, utilities and energy multinationals experienced an increase in the CSR practices during the last decades. The oil and gas undertakings have been among the companies that have championed CSR. This is related to the fact that their activities are linked with high negative environmental effects, such as oil spills, and have a negative influence on the local communities and their living environment [7]. Some environmentalists claim that companies, operating in oil and gas sector, can never become sustainable because production and consumption of oil and gas products are harmful to the environment and cause greenhouse emissions. However, energy undertakings have great potential for mitigating environmental impact and providing investments for the development of their local communities. CSR can as well be a genuine source of differentiation from competitors [13-15].

As the international energy undertakings entered into the global market, their economic, environmental, legal, and social practices have been followed by their global stakeholders. The potential legal risks and possible negative environmental impacts are the core issues for the legitimacy of energy companies' practices. In addition, the leading energy multinationals have to implement advanced technologies and processes as well as provide information and build close cooperation with all stakeholders by emphasizing their CSR practices.

Spence [7] pointed out that undertakings that are operating in oil and gas sectors encounter the following risks: environmental; health and safety; liability and reputational issues, having a critical impact on the companies' competitiveness as well as the long-term success. Taking this into consideration, it is expected that energy multinationals should implement higher environmental and labor management standards and comply with the most important international standards and principles. Therefore, for the energy companies in implementing their CSR practices, it is necessary to take into account the possible negative environmental and social impacts. Energy undertakings are as well facing high corruption, human rights, and health and safety risks. Thus, energy undertakings strive to meet the high standards of CSR by emphasizing sustainable management practices and socially responsible activities [7].

The main international standards that are addressing social issues of energy utilities are the following: United Nations (UN) International Convention on Civil and Political Rights; UN International Convention on Economic, Social, and Cultural Rights; UN Universal Declaration of Human Rights; International Labor Organization (ILO) Declaration on Fundamental Principles and Rights at Work; OECD Guidelines for Multinational Enterprises; ILO Tripartite Declaration Concerning Multinational Enterprises and Social Policy; UN Global Compact; Global Reporting Initiative; Council of Europe's Social Charter; UNCTAD's Multilaterally Agreed Equitable Principles and Rules for the Control of Restrictive Business Practices and Chapter VI on combating bribery, UN Convention against Corruption, etc.

CSR deals with the following economic, social, and environmental issues of energy sector development that are defined below.

As far as the access to safe and reliable energy supply, which is the main precondition for the functioning of modern economies and sustaining high living standards and implementing sustainable development, is in line with the Sustainable Development Goals, the energy sector is the major source of atmospheric, water, and land pollution as well as the largest emitter of greenhouse gasses. In fact, energy undertakings have a long history and experience on environmental issues reporting, in comparison with social issues of their activities, though there is a clear agreement among stakeholders that social issues are a vital element of CSR in the energy sector.

Energy exploration, production, transmission, distribution, and usage have negative environmental impact on ecosystems, human health, workplace, community, and city at national, regional, and global 
levels; thus, energy undertakings are forced to mitigate these environmental impacts during all life cycles of their products. The main negative environmental impacts of companies that are operating in the energy sector that are addressed by the CSR practices are the diminishing and contaminated soil, water and atmospheric pollution, climate change, acidification and eutrophication, loss of biodiversity, radiation and production of radioactive and other solid wastes, etc. The negative environmental impact of energy multinationals causes significant threats especially for developing countries, where a large number of people live without infrastructure, and all environmental problems-caused by the operation of energy companies-affect a greater number of people, who are more vulnerable to these impacts because of lower living standards and limited access to all services. In addition, the development of infrastructure in developing countries for hydro power plants and high-voltage transmission lines has a negative impact on biodiversity rich and ecologically sensitive areas $[13,14]$. Therefore, energy undertakings that are committed to the CSR practices should deal with environmental sustainability requirements. Socially responsible energy utilities need to increase the use of renewable energy sources for energy generation, pursue a long-term strategy for phasing out fossil fuels, and promote energy efficiency in all processes. Other actions and long-term strategies to mitigate climate change and reduce greenhouse gases (GHG) emissions are necessary to comply with environmental obligations of socially responsible companies. Energy undertakings need to ensure public disclose of proper environmental information, linked to their operations by developing indicators and providing monitoring and transparency. Several important international environmental standards for energy undertakings that are operating in developing countries are the following: 1992 Rio Declaration on Environment and Development; Agenda 2030; 1992 Biodiversity Treaty; 1997 Kyoto Protocol and Paris agreement; ISO 14001; Chapter $\mathrm{V}$ on Environment of the OECD Guidelines for Multinational Enterprises. There are other specific international conventions that are addressing the responsibilities of energy multinationals in terms of their environmental impacts [14].

The economic issues of CSR in the energy sector are linked to the impact of economic efficiency and promotion of economic development of countries. It is obvious that energy undertakings must seek profits to support their operations, and these issues have been increasingly debated in terms of CSR practices [2,13]. Energy utilities are expected to contribute to sustainable economic development of host countries by investing in infrastructure, research, and development; providing access to advanced technologies to be used in the future, and guaranteeing security of energy supply for local communities and enterprises.

CSR in the energy sector as well means paying fair taxes and conducting their operations in an honest, transparent, and open manner. Seeking to provide contribution to host country economic development, energy undertakings should evaluate the local needs and define whether additional capacities are required or whether the energy needs could be met through demand-side measures rather than additional supply. Other economic issues of CSR in the energy sector are the promotion of competition, tackling corruption, paying fair taxes as well as promoting and investing in research and development.

Energy multinationals can provide many social benefits to host countries: jobs, investments in infrastructure, and budget revenues from taxes. Nevertheless, many oil-rich countries are experiencing economic underdevelopment, low living standards, poverty, and social unrest due to political mismanagement and military conflicts. As a consequence of oil exploration, these countries experience large inflows of oil revenues, leading to their currency appreciation and making problems for export of agricultural and manufacturing goods. Host country governments receive huge budget revenues from oil companies, which pay taxes but have a negative impact on developing public policies to promote economic growth and quality of life [20,21].

There are a few important cross-cutting aspects linked to all three pillars of sustainable energy supply [5]. The cross-cutting standards are the bottom-line standards that are necessary to implement for energy undertakings, and they consist of a minimum requirement for sustainable energy projects. First of all, it is necessary to comply with all existing laws and regulations, both locally and internationally, 
respect human rights, and mitigate corruption. Other cross-cutting aspects are the following: striving for energy poverty reduction, implementing the precautionary principle, evaluation and mitigation of all risks, transparency, openness, accountability and information dissemination, involvement of stakeholder in decision-making, ensuring wide public participation and engagement [24,25]. The international standards that are linked to cross-cutting issues include the UN Declaration of Human Rights, ILO provision, etc., targeting equity, efficiency, participatory decision-making, sustainability, and accountability, having a positive impact on corruption prevention, which is a serious challenge in the energy sector for achieving sustainable energy development.

\section{Corporate Social Responsibility as the Main Tool for Corruption Risk Mitigation in the Energy Sector}

As it was already mentioned, the risk of corruption is high in the energy sector due to the specifics of this sector and high regulation level. This is the important cross-cutting issue of energy sustainability. However, in contrast to the environmental reporting, the disclosure of information on corruption risks and local community investments is weak in CSR practices and reporting initiatives [8]. In their reports, energy undertakings disclose their spending on education and various philanthropic activities as well as on stakeholders' participation and involvement in their operations and decision-making. However, these companies do not report on how effectively the money has been spent. Based on such reporting, and publicly available information, it is difficult to assess the benefits for local communities. Some studies proved that many community projects that are initiated by energy companies in developing countries were badly planned and were ineffective. This is linked to the fact that energy multinationals, operating in corrupt environments of developing countries, always have a poorly developed legal system and law enforcement. Consequently, some corporate social initiatives are just narrow philanthropic gestures, which do not provide long-term benefits for local communities [16].

If governments have done their jobs in public governance properly, there would be no need for CSR and other voluntary initiatives, as companies would be forced to deal with environmental and social problems in realizing their business opportunities. This ability of the government to provide good quality of governance can be assessed by regulatory quality indicators. The regulatory quality indicator that was developed by World Bank measures the public perceptions of the ability of the governmental institutions and regulatory bodies to enforce necessary policies that promote business development. This indicator is calculated by combining several indicators from various areas linked to the sphere of governmental regulation. The regulatory quality indicators can take a value in the range between -2.5 and 2.5 . The higher value shows a better regulatory quality in the country. The regulation quality has the opposing effects on corruption prevention by promoting transparency in the energy sector. The Freedom from Corruption provided by Heritage Foundation is an indicator that measures the level of corruption perception in the range between 0 and 100, where the highest score shows that there is no corruption, and the lowest score shows the highest corruption level [68].

International CSR initiatives provided various tools for business forcing energy companies to take into account social and environmental issues of their operations. Seeking to define what are the best-practice CSR policies in the energy sector helps to deal with the most critical social issue, i.e., corruption; it is necessary to assess how energy undertakings are implementing these standards via CSR practices. The main international CSR instruments for energy undertakings are the following: UN Global Compact, OECD Guidelines for Multinational Enterprises, Carbon Disclosure Project (CDP), Global Reporting Initiative (GRI) G3 Guidelines, UN Convention against Corruption. The UN Global Compact and the OECD Guidelines for Multinational Enterprises are international standards for socially responsible and ethical business conduct. The CDP and GRI G3 Guidelines provide reporting guidelines for businesses in order to disclose information on relevant CSR issues for the stakeholders. The UN Convention against Corruption is the most comprehensive tool to mitigate corruption risks 
within the business. These instruments provide initiatives for energy undertakings for reporting on a wide range of social, economic, environmental, and cross-cutting issues.

The Global Compact provides opportunities for energy undertakings to share experience and practices on developing business strategy, corporate image, and reputation as well as improve the corruption risk management strategy [47-50]. The company or organization entering Global Compact agreement is included in the list of Global Compact members, and its social responsibility practices are published on the Internet. This, in itself, makes a big advertisement for the entire organization and raises the image of its brand in the eyes of the consumers. The Global Compact Agreement is based on the public accountability, transparency, and willingness of business to participate in the independent actions in implementing the principles of the Global Compact. It is based on the principles of human and labor rights, environmental protection, and anti-corruption.

Non-compliance with CSR in the future may lead to the loss of competitiveness. A responsible and ethical company should be responsible for every activity that influences people, their communities, and the environment. It is safe to say that CSR is an inevitable necessity of today. CSR is measured and institutionalized on the basis of four key parameters: (a) markets, (b) employment, (c) public and (d) environmental protection. Based on these parameters, CSR strategies are developed, specifying and adapting corporate management to specific conditions. Socially responsible behavior of the organization is created by selecting values (principles, norms, rules), according to their ability to promote functionality, economic efficiency, and business competitiveness; at the same time, such optimization of activities must be combined with human rights, dignity, the unconditional value of life, etc. Thus, there is a need for business ethics when pragmatism and morality, economy and ethics are combined [24].

It should be noted that the participation in all the mentioned CSR does not necessarily guarantee that energy undertakings are operating responsibly and implementing all standards into practice. It is necessary to ensure the compliance in practice and performing of audits $[55,56]$. There are as well complaint procedures that can be applied by stakeholders, according to the OECD Guidelines; however, the complaints procedure for the Global Compact is non-existent in practice. The reporting based on the CDP and GRI guidelines provides that energy undertaking is aware of the most important CSR issues, but it does not provide evidence of their importance for the enterprise in practice. Some companies that are behaving in a responsible manner have not signed Global Compact or OECD Guidelines and do not report on social and environmental impacts of their activities. Nevertheless, the official implementation of these international CSR practices gives a good indication of socially responsible intentions of energy undertakings.

The United Nations Global Compact is a "strategic policy initiative for businesses that are committed to aligning their operations and strategies with ten universally accepted principles in the areas of human rights, labor, environment, and anti-corruption". The main ten principles of Global Compacts are based on the following documents: The Universal Declaration of Human Rights, The ILO's Declaration on Fundamental Principles and Rights at Work, The Rio Declaration on Environment and Development, and The United Nations Convention against Corruption [13].

The UN Global Compact (GC) is a partnership initiative and does not involve compliance procedure; nevertheless, there are "integrity measures" based on the dialogue around allegations of systematic and egregious abuse of Global Compact principles. Therefore, stakeholders are encouraged to raise concerns about the firm's alleged non-compliance with GC principles. Though the integrity measures have been invoked less than 100 times since the initiative's inception, none of them has provided for the termination of the firm's GC membership. Nevertheless, the initiated dialogue may lead to the improvements of corporate behavior of the companies due to the negative publicity that was achieved during the integrity procedures [1,2].

Though GC principles are not specific to the energy industry, they cover important issues that are relevant to the energy undertakings: freedom of association, powers of collective bargaining, human rights, elimination of forced and child labor, inequality and gender discrimination, precautionary 
approach and greater environmental protection. After signing up to the initiative, energy companies must provide regular updates and reports on their progress in implementing ten principles of GC. There is an obligatory structure of reporting, and companies can choose their report template in order to address ten principles of GC [2].

The OECD Guidelines are more specific comparing with GC. Though OECD Guidelines are not sector specific, they cover a wide range of CSR issues that are relevant to the energy sector in ten chapters: environmental protection, labor rights, corruption prevention and human rights, disclosure of information, fair taxation, and sustainable supply chain management.

The CDP issues the annual request for information on behalf of institutional investors, purchasing organizations, and government bodies. Literature shows that energy sector companies have the highest scores in term of responding to the CDP (at 93\%). It is a positive trend to take into account the enormous importance of the energy sector in climate change mitigation [2].

The Global Reporting Initiative is an international CSR practice and reporting initiative based on framework setting out the principles as well as indicators for assessing and reporting on enterprise economic, environmental, and social performance. Energy sector-specific disclosure areas are the following: availability of skilled workforce, percentage of employees that are eligible to retire in the next 5 and 10 years, policies on health and safety of employees, percentage of total workers in formal health and safety committees for monitoring occupational health and safety programs, health and safety issues that are addressed in formal trade unions agreements, programs for lifelong learning, percentage of employees that are receiving regular performance and career development reviews, etc.

All discussed CSR initiatives that are implemented in energy sector highlight the responsibility of energy undertakings to ensure that all environmental, social, and other standards are implemented throughout the supply chain of undertakings as well. The Global Compact applies "sphere of influence" to address the supply chain and requires enterprises to implement GC principles within the sphere of their influence, i.e., GC requires implementing CSR beyond the individual company level. OECD Guidelines address supply chain issue and require a firm to ensure its suppliers to manage the climate-related risks as well. Energy undertakings are required to report to the CDP together with all their suppliers and complete all questionnaires linked to the GHG emissions, energy consumption and cost, and climate change mitigation strategies [4]. The GRI provides the following specific disclosure areas in the energy sector: policies and requirements regarding health and safety, days worked by suppliers' employees, percentage of suppliers' employees that have undergone relevant health and safety training, benefits provided to the full-time employees, percentage of significant suppliers that have undergone screening on human rights.

In dealing with corruption, all CSR initiatives are obliged to use comparably new international CSR instrument: the UN Convention against Corruption. The UN Convention against Corruption noted that it is not a traditional CSR tool as CG, GRI, or CDC, but a very relevant one for dealing with cross-cutting issues linked to anti-corruption. Other initiatives, for example, the Extractive Industry Transparency Initiative, are proved to be inefficient [4].

As corruption risks were usually mitigated by developing strong legal frameworks on international and national levels, the CSR practitioners were more concentrated on environmental and social issues and left corruption aside. However, the CSR initiatives in cooperation with the business and other stakeholders should strive to implement the UN Convention against Corruption, which is the most effective tool to mitigate corruption risks on all levels. The treaty sets obligations and recommendations that may have significant influence on business, especially in the energy sector. The preventive anti-corruption policies and practices in the private sector should be developed, and the bribery of foreign public officials as well as in the private and public sectors should be criminalized. The Convention requires ensuring that legal persons that are held liable are subject to criminal or non-criminal sanctions, including monetary sanctions. The CSR practitioners should force governments to implement the Convention. All business communities, especially in the energy sector, need to apply transparent business standards that are set by the Convention, as this will provide benefit and fair 
competition for all. Therefore, CSR movement and, most importantly, the energy enterprises, which are committed to higher CSR standards, should influence governments to implement the requirements set by the Convention.

All international anti-corruption initiatives and standards provide recommendations for companies that in order to deal with corruption risks, firms should prepare the risk management plan, covering the corruption prevention, evaluation, and monitoring issues. In order to minimize the corruption risks, the anti-corruption programs should include the highest standards of the corruption awareness, which the top managers are required to pass to all employees and accordingly fulfill in the employers' contracts. The disclosure and dissemination of information are necessary to ensure effective implementation of anti-corruption programs. All relevant information should be provided on the firm's website, including corruption prevention programs, codes of ethics, corruption prevention procedures and recommendation, including reports on implementation of anti-corruption programs.

The empirical results $[9,13-16,21,25]$ show that firms with higher standards of CSR have lower corruption risk levels, as CSR mitigates corruption risk at enterprise level very well. This is as well linked with the country-level CSR. The institutional quality, energy market development, legislation for investors' protection and freedom of the press as well strengthens the positive impact of CSR on the corruption mitigation at the enterprise level. The empirical results proved the differences between developed and emerging energy markets in terms of CSR engagement, having impact on corruption risk. There is a strong relationship between CSR-corruption risk level and the level of energy market development. In the emerging energy markets, the interaction between institutional quality and CSR has a positive mitigating effect on the corruption risk mitigation. However, in developed energy market, this interaction is not remarkably strong. The interaction of the freedom of the press and CSR provides the strongest influence on corruption risk mitigation in the emerging markets. This is linked to the fact that developed energy markets already have freedom of press and high-quality institutions, and the increase in institutional quality or freedom of the press has no significant influence on corruption risk mitigation. All empirical results show the importance of institutional quality for the analysis of the CSR impact on the corruption risk mitigation. In the section that follows, which is based on the literature review and analysis, the authors develop a model for corruption risk mitigation in the energy sector.

\section{Model for Corruption Risk Mitigation in the Energy Sector}

In order to mitigate corruption risk in the energy sector, it is necessary to guarantee the complete commitment of all stakeholders in building integrity and struggling with corruption in the energy sector. The involvement of civil society and the private sector, as well as legislators, regulators, and system of justice, is necessary to protect and share the usage of energy resources in the country. The disclosure and dissemination of information and data is necessary to support the development of anti-corruption actions and the advance of anti-corruption programs to ensure the impact of such programs on corruption prevention in the country.

The government should guide these processes, and the necessary steps are as follows:

(a) to ensure a multi stakeholder approach;

(b) to produce reliable data on the extent of corruption in the energy sector and assess the economic and social costs associated with corruption;

(c) to put the principles of transparency, accountability, participation, and anti-corruption in practice.

In Figure 1, four main issues of dealing with corruption risks in the energy sector are addressed. It is necessary to stress that in developed economies, transparency, accountability, and participation are ensured by laws and strong regulation institutions, which are able to enforce these laws. However, in developing countries with lower institutional indicators, the situation requires more efforts and actions. 


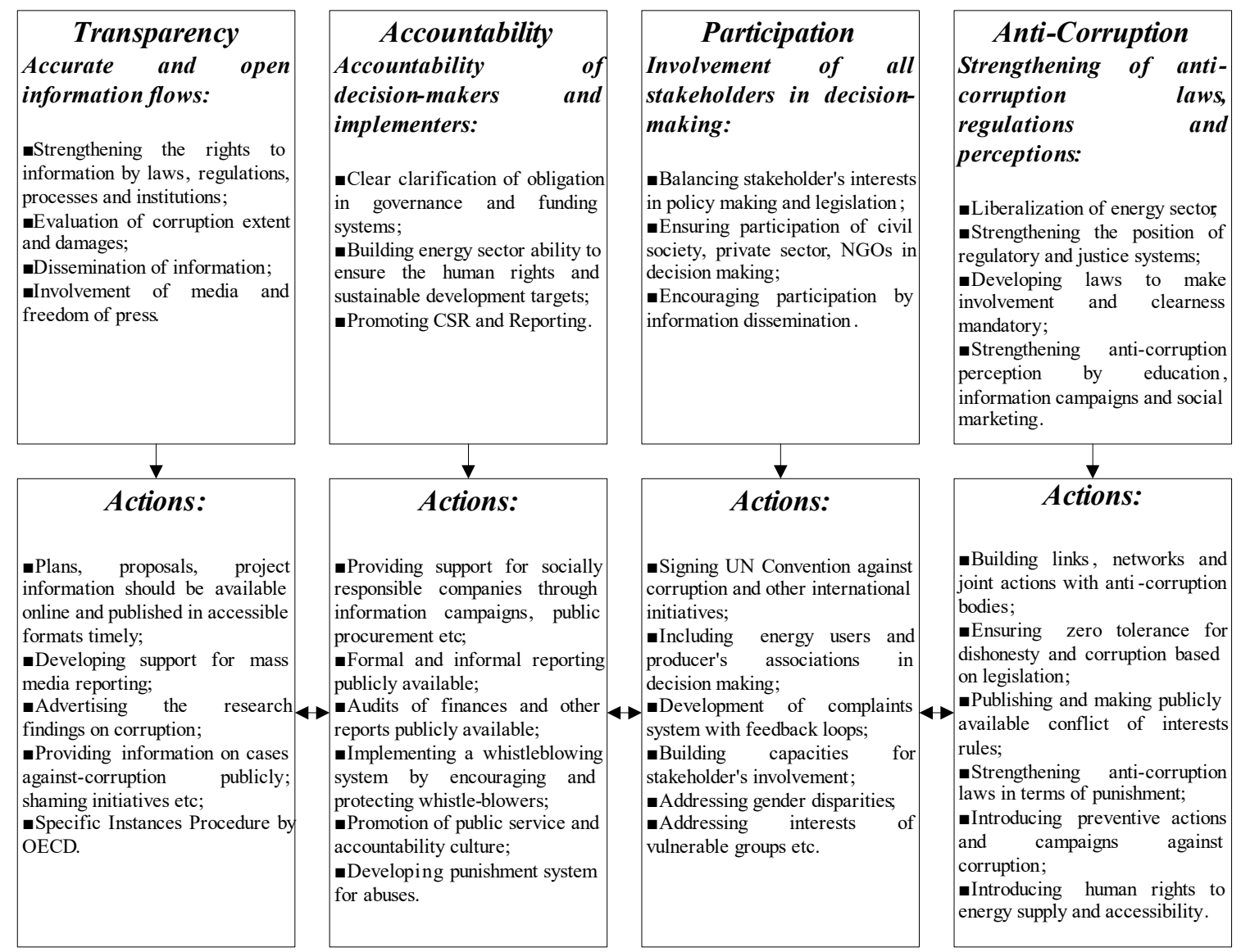

Figure 1. Corruption risk mitigation measures in the energy sector; Source: Own results based on [72,73].

As one can see from Figure 1, the developed model includes an active role of government in combating corruption in the energy sector. However, the roles of business companies and all other stakeholders are important as well. Governments should create a favorable environment for businesses to operate without bribes and achieve a competitive advantage by implementing CSR policies and instituting systems and policies to mitigate corruption risks [4,9]. International CSR initiatives create good opportunities for companies to avoid corruption as companies engaging in socially responsible behaviors are more resistant to corruption risks.

\section{Conclusions}

Sustainable energy development is the main condition of national security, social stability, and economic growth. In addition, energy plays a vital role in economics, politics, and people's livelihood. Corruption is a cross-cutting issue in terms of sustainability and has a negative impact on all other economic, social, and environmental issues of sustainable energy development, as it is among the most important challenges of the energy sector due to specific features, making it especially vulnerable to corruption. The geopolitical situation, energy, dependency, and abundance of governmental control and regulation provide good conditions for corruption risk. Governments play the major role in adopting specific regulations and procedures for private business, issuing licenses and permits, making decisions regarding pricing structure, allocating public support for renewables, etc.

In order to deal with corruption risk in the energy sector, it is necessary to guarantee the complete commitment of all stakeholders in building integrity and struggling with corruption. The involvement of civil society and the private sector, as well as legislators, regulators, and system of justice, is necessary to protect and share the usage of energy resources in the country. 
Due to the increased demand from the stakeholders and regulators for ethical behavior and legal compliance of energy undertakings, the firms in the energy sector are forced to implement various anti-corruption programs and management systems to mitigate the corruption risk. CSR can play a vital role in dealing with corruption in the energy sector at the enterprise level. Anti-corrupt standards are the main supporting means to achieve other CSR goals and principles; therefore, the mitigation of corruption risks should be a priority for socially responsible companies, operating in the energy sector. The effective implementation of anti-corruption standards can be ensured by Global Compact and Global Reporting Initiative and other international initiatives that are requiring companies to deal with corruption risks and report on their corruption mitigation practices and achievements. The UN Convention against Corruption can provide many benefits for energy undertakings due to leveling the playing field between competitors in the energy sector. The CSR initiatives provide a privileged position for socially responsible energy undertakings as they can implement the commitments made by the Parties of Convention into everyday business practice.

All international anti-corruption initiatives and standards provide recommendations for companies: in order to deal with corruption risks, firms should prepare a risk management plan that is covering corruption prevention, evaluation, and monitoring issues. In order to minimize corruption risks, the anti-corruption programs should include the highest standards of corruption awareness, which the top managers are required to pass to all employees and accordingly fulfill in the employer's contracts. Information disclosure and dissemination are necessary to ensure effective implementation of anti-corruption programs. All relevant information should be provided on the firm's website, including corruption prevention programs, codes of ethics, corruption prevention procedures and recommendation, including reports on implementation of anti-corruption programs.

National legal system and institutional indicators play an important role in defining the effectiveness of CSR to deal with corruption in the energy sector, as other important issues, such as market liberalization level, regulatory quality, investor protection, and freedom of the press, are important to mitigate corruption risk.

The research conclusions in this study can help local governments formulate local policies and regulations and promote sustainable energy development with a comprehensive consideration of local economic development, industrial structure, financial balance of citizens, as well as population size and structures.

The main limitation of the conducted study is the lack of the empirical evidence. The future research is necessary for conducting the empirical study and testing the developed theoretical model of corruption risk mitigation in the energy sector.

In addition, some future research is also necessary for better understanding in which situations and under which circumstances, energy companies are prone to corruption risks, how anti-corruption programs are implemented in the energy undertakings and are effective in dealing with corruption risks under international CSR initiatives. In order to get more insights about benefits of corruption risk mitigation, the impact of anti-corruption programs and corruption risk mitigation actions that are implemented in the energy companies on their competitiveness needs to be further investigated.

Author Contributions: Conceptualization, J.L., L.R., W.S. and J.S.; Methodology, W.S.; Validation, S.Y.; Formal analysis, W.S. and J.Q.; Investigation, J.Q. and L.R.; Data curation, S.Y.; Supervision, L.R.; Writing-original draft preparation, J.L. and J.S.; Writing-review and editing, J.L. and W.S.

Funding: This work was supported by the Program for the Philosophy and Social Sciences Research of Higher Learning Institutions of Shanxi (PSSR: 2017336) and Taiyuan University of Science and Technology Scientific Research Initial Funding (TYUST SRIF No. W20182014 and No. W20192003).

Acknowledgments: The authors thank the anonymous reviewers and all the editors in the process of manuscript revision.

Conflicts of Interest: The authors declare no conflict of interest. 


\section{References}

1. Streimikiene, D.; Simanaviciene, Z.; Kovaliov, R. Corporate social responsibility for implementation of sustainable energy development in Baltic States. Renew. Sustain. Energy Rev. 2009, 13, 813-824. [CrossRef]

2. Stjepcevic, J.; Siksnelyte, I. Corporate Social Responsibility in Energy Sector. Transform. Bus. Econ. 2017, 16, 21-33.

3. World Energy Council. World Energy Trilemma Index 2018. Available online: https://www.worldenergy.org/ publications/2018/trilemma-report-2018/ (accessed on 6 April 2019).

4. Rimsaite, L. Corruption risk mitigation in energy sector: Issues and challenges. Energy Policy 2019, 125, 260-266. [CrossRef]

5. Kolk, A. The social responsibility of international business: From ethics and the environment to CSR and sustainable development. J. World Bus. 2016, 51, 23-34. [CrossRef]

6. Gennaioli, C.; Tavoni, M. Clean or dirty energy: Evidence of corruption in the renewable energy sector. Public Choice 2016, 166, 261-290. [CrossRef]

7. Spence, D.B. Corporate social responsibility in the oil and gas industry: The importance of reputational risk. Chi. Kent L. Rev. 2011, 86, 59-85.

8. Mezher, T.; Tabbara, S.; Al-Hosany, N. An overview of CSR in the renewable energy sector Examples from the Masdar Initiative in Abu Dhabi. Manag. Environ. Qual. 2010, 21, 744-760. [CrossRef]

9. Krishnamurti, C.; Shams, S.; Velayutham, E. Corporate social responsibility and corruption risk: A global perspective. J. Contemp. Account. Econ. 2018, 14,1-21. [CrossRef]

10. Kim, Y.; Park, M.S.; Wier, B. Is earnings quality associated with corporate social responsibility? Account. Rev. 2012, 87, 761-796. [CrossRef]

11. Gao, F.; Lisic, L.L.; Zhang, I. Commitment to social good and insider trading. J. Account. Econ. 2014, 57, 149-175. [CrossRef]

12. Kim, Y.; Li, H.; Li, S. Corporate social responsibility and stock price crash risk. J. Bank Financ. 2014, 43, 1-13. [CrossRef]

13. Du, S.; Vieira, E.T. Striving for Legitimacy Through Corporate Social Responsibility: Insights from Oil Companies. J. Bus. Ethics 2012, 110, 413-427. [CrossRef]

14. Symon, A. Ethical Business Practice or camouflage? Energy and Mining companies and Corporate Social Responsibility. In A New Energy Frontier: The Bay of Bengal Region; Devare, S.T., Ed.; Manohar Publications: Delhi, India, 2008; pp. 168-182.

15. Vicente, P. Does oil corrupt? Evidence from a natural experiment in West Africa. J. Dev. Econ. 2010, 92, $28-38$. [CrossRef]

16. Guenther, E.; Hoppe, H.; Poser, C. Environmental Corporate Social Responsibility of Firms in the Mining and Oil and Gas Industries: Current Status Quo of Reporting Following GRI Guidelines. In Greener Management International; Greenleaf Publishing: Sheffield, UK, 2006; Available online: https://www.jstor.org/stable/ greemanainte.53.7 (accessed on 12 April 2019).

17. Jenkins, H.; Yakovleva, N. Corporate Social Responsibility in the Mining Industry: Exploring Trends in Social and Environmental Disclosure. J. Clean. Prod. 2006, 14, 271-284. [CrossRef]

18. Lovei, L.; McKechnie, A. The Costs of Corruption for the Poor-The Energy Sector. Viewpoint. Available online: http://hdl.handle.net/10986/11437 (accessed on 22 May 2019).

19. Hilson, G.; Basu, A.J. Devising Indicators of Sustainable Development for the Mining and Minerals Industry: An Analysis of Critical Background Issues. Int. J. Sustain. Dev. World Ecol. 2003, 10, 319-331. [CrossRef]

20. Kolk, A.; Lindeque, J.; Buuse, D.V.D. Regionalization strategies of EU electric utilities. Brit J. Manag. 2013, 25, 77-99. [CrossRef]

21. Zhao, W. Corporate Social Responsibility in the Energy Industry: A Content Analysis of Leading Energy Companies' Websites. Available online: http://www.diginole.lib.fsu.edu/islandora/object/fsu: 253157/datastream/PDF/view (accessed on 28 March 2019).

22. Hult, G.T.M. Market-focused sustainability: Market orientation plus! J. Acad. Mark. Sci. 2011, 39, 1-6. [CrossRef] 
23. Jovovic, R.; Simanaviciene, Z.; Dirma, V. Assessment of Heat Production Savings Resulting from Replacement of Gas with Biofuels. Transform. Bus. Econ. 2017, 16, 34-51.

24. Kerckhoffs, T.; Wilde-Ramsing, J. European Works Councils and Corporate Social Responsibility in the European Energy Sector. In Centre for Research on Multinational Corporations; SOMO: Amsterdam, The Netherlands, 2010.

25. Calabrese, A.; Costa, R.; Menichini, T.; Rosati, F. Does corporate social responsibility hit the mark? A stakeholder oriented methodology for CSR assessment. Knowl. Process. Manag. 2013, 20, 77-89. [CrossRef]

26. Park, J.; Lee, H.; Kim, C. Corporate social responsibilities, consumer trust and corporate reputation: South Korean consumers' perspectives. J. Bus. Res. 2014, 67, 295-302. [CrossRef]

27. Kim, H.; Youn, S.; Lee, D. The effect of corporate social responsibility reputation on consumer support for cause-related marketing. Total Qual. Manag. Bus. Excell. 2019, 30, 682-707. [CrossRef]

28. Stanisavljević, M. Does Customer Loyalty Depend on Corporate Social Responsibility. J. Contemp. Issue. Econ. Bus. 2017, 63, 38-46. [CrossRef]

29. Yuen, K.F.; Thai, V.V.; Wong, Y.D. Are customers willing to pay for corporate social responsibility? A study of individual-specific mediators. Total Qual. Manag. Bus. Excell. 2016, 27, 912-926. [CrossRef]

30. Pätäri, S.; Jantunen, A.; Kyläheiko, K.; Sandström, J. Does Sustainable Development Foster Value Creation? Empirical Evidence from the Global Energy Industry. Corp. Soc. Responsib. Environ. Manag. 2012, 19, 317-326. [CrossRef]

31. Du, S.; Bhattacharya, C.B.; Sen, S. Maximizing business returns to corporate social responsibility (CSR): The role of CSR communication. Int. J. Manag. Rev. 2010, 12, 8-19. [CrossRef]

32. Nazari, K.; Parvizi, M.; Emami, M. Corporate social responsibility: Approaches and perspectives. Interdiscip. J. Contemp. Res. Bus. 2012, 3, 554-563.

33. Schaltegger, S.; Synnestvedt, T. The link between 'green' and economic success: Environmental management as the crucial trigger between environmental and economic performance. J. Environ. Manag. 2002, 65, 339-346.

34. Dyllick, T.; Hockerts, K. Beyond the business case for corporate sustainability. Bus. Strat. Environ. 2002, 11, 130-141. [CrossRef]

35. Doh, J.P.; Guay, T.R. Corporate Social Responsibility, Public Policy, and NGO Activism in Europe and the United States: An Institutional- Stakeholder Perspective. J. Manag. Stud. 2006, 43, 47-73. [CrossRef]

36. Dummett, K. Drivers for Corporate Environmental Responsibility (CER). Environ. Dev. Sustain. 2006, 8, 375-389. [CrossRef]

37. Willis, A. The Role of the Global Reporting Initiative's Sustainability Reporting Guidelines in the Social Screening of Investments. J. Bus. Ethics 2003, 43, 233-237. [CrossRef]

38. Danilet, M.; Mihai, O. CSR Online Discourse Practices in the Romanian Energy Sector. J. East. Eur. Res. Bus. Econ. 2013, 2013, 1-9. [CrossRef]

39. Dyduch, J.; Krasodomska, J. Determinants of Corporate Social Responsibility Disclosure: An Empirical Study of Polish Listed Companies. Sustainability 2017, 9, 1934. [CrossRef]

40. Ali, W.; Frynas, J.G. The Role of Normative CSR-Promoting Institutions in Stimulating CSR Disclosures in Developing Countries. Corp. Soc. Responsib. Environ. Manag. 2018, 25, 373-390. [CrossRef]

41. Gul, S.; Muhammad, F.; Rashid, A. Corporate Governance and Corporate Social Responsibility: The Case of Small, Medium, and Large Firms. Pak. J. Commer. Soc. Sci. 2017, 11, 1-34.

42. Dreher, A.; Siemers, L.H.R. The intriguing nexus between corruption and capital account restrictions. Public Choice 2009, 140, 245-265. [CrossRef]

43. Ali, W.; Frynas, J.G.; Mahmood, Z. Determinants of Corporate Social Responsibility (CSR) Disclosure in Developed and Developing Countries: A Literature Review. Corp. Soc. Responsib. Environ. Manag. 2017, 24, 273-294. [CrossRef]

44. Danubianu, M.; Teodorescu, C. Impact of corporate social responsibility on sustainable enterprise development. Present Environ. Sustain. Dev. 2017, 11, 129-139. [CrossRef]

45. Zink, K.J. Stakeholder orientation and corporate social responsibility as a precondition for sustainability. Total Qual. Manag. Bus. Excell. 2007, 16, 1041-1052. [CrossRef]

46. Kolk, A.; Tulder, R.V. International business, corporate social responsibility and sustainable development. Int. Bus. Rev. 2010, 19, 119-125. [CrossRef] 
47. Kell, G. The Global Compact. Selected Experiences and Reflections. J. Bus. Ethics 2005, 59, 69-79. [CrossRef]

48. Whitehouse, L. Corporate Social Responsibility, Corporate Citizenship and the Global Compact: A New Approach to Regulating Corporate Social Power? Glob. Soc. Policy 2003, 3, 299-318. [CrossRef]

49. Runhaar, H.; Lafferty, H. Governing Corporate Social Responsibility: An Assessment of the Contribution of the UN Global Compact to CSR Strategies in the Telecommunications Industry. J. Bus. Ethics 2009, 84, 479-495. [CrossRef]

50. Coulmont, M.; Berthelot, S.; Paul, M. The Global Compact and its concrete effects. J. Glob. Responsib. 2017, 8, 300-311. [CrossRef]

51. Errath, B.; Brew, P.; Moberg, J.; Brooks, J.; Cote-Freeman, S. Business Against Corruption: A Framework for Action: Implementation of the 10th UN Global Compact Principle Against Corruption. Available online: https://www.globalcompact.org (accessed on 8 May 2019).

52. Dreher, A.; Gassebner, M. Greasing the wheels? The impact of regulations and corruption on firm entry. Public Choice 2013, 155, 413-432. [CrossRef]

53. Bhattacharyya, S.; Hodler, R. Natural resources, democracy and corruption. Eur. Econ. Rev. 2010, 54, 608-621. [CrossRef]

54. Szczepankiewicz, E.I.; Mućko, P. CSR Reporting Practices of Polish Energy and Mining Companies. Sustainability 2016, 8, 126. [CrossRef]

55. McQueen, D. CSR and New Battle Lines in Online PR War: A Case Study of the Energy Sector and its Discontents. Dev. Cor. Govern. Responsib. 2015, 7, 99-125.

56. Ali, W.; Faisal Alsayegh, M.; Ahmad, Z.; Mahmood, Z.; Iqbal, J. The Relationship between Social Visibility and CSR Disclosure. Sustainability 2018, 10, 866. [CrossRef]

57. An, Y.; Qiao, X.; Zhai, S.; Zheng, X. Online Social Responsibility Reporting at Universities: A Comparative Study between New Zealand and Hong Kong. Transform. Bus. Econ. 2018, 17, 479-506.

58. Hilson, G.M. Improving Environmental, Economic and Ethical Performance in the Mining Industry. Part 1. Environmental Management and Sustainable Development. J. Clean. Prod. 2006, 14, 225-462. [CrossRef]

59. Gouldson, A.; Bebbington, J. Corporations and the Governance of Environmental Risk. Environ. Plan. C Gov. Policy 2007, 25, 4-20. [CrossRef]

60. Carroll, A.B. Carroll's pyramid of CSR: Taking another look. Int. J. Corp. Soc. Responsib. 2016, 1, 3. [CrossRef]

61. Boström, M. A missing pillar? Challenges in theorizing and practicing social sustainability: Introduction to the special issue. Sustain. Sci. Pract. Policy 2017, 8, 3-14. [CrossRef]

62. Danubianu, M.; Teodorescu, C. Managerial Tools and Sustainable Development. Present Environ. Sustain. Dev. 2016, 10, 151-160. [CrossRef]

63. Husted, B.W. Wealth, culture, and corruption. J. Int. Bus. Stud. 1999, 30, 339-359. [CrossRef]

64. Treisman, D. The causes of corruption: A cross-national study. J. Public Econ. 2000, 76, 399-457. [CrossRef]

65. Lederman, D.; Loayza, N.V.; Soares, R.R. Accountability and corruption: Political institutions matter. Econ. Politics 2005, 17, 1-35. [CrossRef]

66. Freille, S.; Haque, M.E.; Kneller, R. A contribution to the empirics of press freedom and corruption. Eur. J. Politics Econ. 2007, 23, 838-862. [CrossRef]

67. Koudelková, P.; Strielkowski, W.; Hejlová, D. Corruption and system change in the Czech Republic: Firm-level evidence. DANUBE Law Econ. Rev. 2015, 6, 25-46. [CrossRef]

68. Barbara, K.H. Transparency in Corporate Reporting: Assessing the World's Largest Companies. Available online: https://www.transparency.org/files/content/feature/2014_TICR_FAQ_EN.pdf (accessed on 14 May 2019).

69. Woo, C.K.; King, M.; Tishler, A.; Chow, L.C.H. Costs of electricity deregulation. Energy 2006, 31, 747-768. [CrossRef]

70. Thomas, S.D. Electricity industry reforms in smaller European countries and the Nordic experience. J. Dev. Econ. 2006, 31, 788-801. [CrossRef]

71. Neuhoff, K.; De Vries, L. Insufficient incentives for investment in electricity generation. Util. Policy 2004, 12, 253-267. [CrossRef] 
72. Transparency International. A Handbook for Communicators and Journalists on Climate Change and Corruption. Available online: https:/www.corruptionwatch.org.za/wp-content/uploads/2017/05/2017_ Media-Handbook_Climate-change-and-corruption.pdf (accessed on 14 May 2019).

73. Water Integrity Network. Water Integrity Global Outlook 2016. Available online: https://www. waterintegritynetwork.net/wigo/ (accessed on 11 May 2019).

(C) 2019 by the authors. Licensee MDPI, Basel, Switzerland. This article is an open access article distributed under the terms and conditions of the Creative Commons Attribution (CC BY) license (http://creativecommons.org/licenses/by/4.0/). 